\title{
Factor-V Leiden G1691A and prothrombin G20210A polymorphisms in Sudanese women with preeclampsia, a case -control study
}

Nadir A. Ahmed', Ishag Adam², Salah Eldin G. Elzaki ${ }^{3}$, Hiba A. Awooda ${ }^{1}$ and Hamdan Z. Hamdan ${ }^{1 *}$ (D)

\begin{abstract}
Background: Preeclampsia can lead to adverse maternal and perinatal outcomes. There are few studies on the association of preeclampsia with thrombophilia in Africa including Sudan.

Methods: A case -controls study was conducted at Saad Abualila Hospital in Khartoum, Sudan during the period of February through November 2017. The cases were women with preeclampsia and healthy pregnant women were the controls (180 women in each arm of the study). Genotyping for Factor-V Leiden 1691G/A and Prothrombin gene variation 20210G/A was done by polymerase chain reaction-restriction fragment length polymorphism (PCR-RFLP).

Results: There was no significant difference in the age, parity, body mass index (BMI) and the other characteristics between the cases and the controls. Genotypes distribution of Factor V Leiden 1691G/A and prothrombin gene 20210G/ A in controls was in accordance with the Hardy-Weinberg equilibrium $(P>0.05)$. The factor $\vee$ Leiden-variation was present in $9.6 \%$ of the cases compared with $0.6 \%$ of the controls, $P<0.001(\mathrm{OR}=18.60,95 \% \mathrm{Cl}=2.38-136.1)$. Only 4 patients with severe preeclampsia had homozygous variation A/A and it was not detected in the controls. Prothrombin G20210A variations not detected neither in the cases nor in the controls group.
\end{abstract}

Conclusions: High prevalence of Factor V Leiden 1691G/A variation in preeclamptic patients compared to controls suggest an involvement of this variation in predisposing to preeclampsia in this setting.

Keywords: Factor V Leiden1691G/A, prothrombin20210G/A, Polymorphism, Factor II, Factor V, Preeclampsia, Sudan

\section{Background}

Preeclampsia is defined as occurrence of hypertension during pregnancy and the presence of proteinuria after the 20th week of gestation in previously normotensive woman [1]. Preeclampsia is a multisystem disorder and one of the most common encountered serious pregnancy-related disease that affects around $3-8 \%$ of all human pregnancies [2, 3].

Although the exact etiology of preeclampsia is not fully understood, the main pathophysiology is the inadequate development of the early placenta "poor placentation",

\footnotetext{
* Correspondence: hamdanology@hotmail.com

${ }^{1}$ Department of Biochemistry and Molecular Biology, Faculty of Medicine,

Al-Neelain University, P.O. Box: 12702, Khartoum, Sudan

Full list of author information is available at the end of the article
}

reduced capacity of the utero-placental circulation which can lead to endothelial dysfunction and the initiation of preeclampsia $[4,5]$.

Preeclampsia has gene variations; however the precise patho-mechanism and genetic basis of preeclampsia remains unknown [6]. The association of Factor-V (rs6025) and Factor II (Prothrombin) (rs1799963) variations with preeclampsia and their possible role in the pathogenesis of preeclampsia have been previously investigated [7]. The results, however, are still inconclusive and contradictory. While some studies reported association between preeclampsia and Factor-V Leiden [8-10], others fail to find an association [11, 12]. Likewise, prothrombin G20210A variation were associated with sever preeclampsia in some studies [13, 14], others found no association $[15,16]$.

(c) The Author(s). 2019 Open Access This article is distributed under the terms of the Creative Commons Attribution 4.0 International License (http://creativecommons.org/licenses/by/4.0/), which permits unrestricted use, distribution, and 
Preeclampsia/eclampsia is the major health problem and associated with high maternal and perinatal mortality in Sudan $[17,18]$. There are few published data on Factor-V Leiden, Prothrombin G20210A variations and preeclampsia in Africa and there is no published data on Factor-V Leiden, Prothrombin G20210A variations and preeclampsia in Sudan [19, 20]. Therefore, the current study was conducted to assess Factor- $V$ Leiden and Prothrombin variation in Sudanese women with preeclampsia.

\section{Methods}

A case -controls study (180 women in each arm) was conducted at Saad Abualila Maternity Tertiary Hospital in Khartoum, Sudan during the period of February through November 2017.

Pregnant women with preeclampsia (blood pressure $\geq$ $140 / 90 \mathrm{mmHg}$ on 2 occasions, at least $6 \mathrm{~h}$ apart, and proteinuria of $\geq 300 \mathrm{mg} / 24 \mathrm{~h}$ ) were the cases. Preeclampsia was classified in mild and severe form. Severe preeclampsia was considered in the occurrence of one or more of the followings; blood pressure $\geq 160 / 110 \mathrm{mmHg}$, proteinuria of $\geq 5 \mathrm{~g} / 24 \mathrm{~h}$ and HELLP syndrome "hypertension, proteinuria and presence of hemolysis, elevated liver enzymes and low platelet count" [1].

The controls were healthy pregnant women without hypertension or proteinuria or diabetes or any underlying disease such as thyroid disorders.

After signing an informed consent, clinical and obstetrics history (age, parity, and gestational age) were gathered using a questionnaire. The Body Mass Index (BMI) was computed from the measured weight and height as weight in $\mathrm{kg} /$ square height in meter. Then $3 \mathrm{~mL}$ of whole blood collected in Ethylene diamine tetra acetic acid (EDTA) was used to extract DNA using salting out method [21]. The detection of Factor-V Leiden G1691A and Prothrombin G20210A variations was based on examination of the size of the polymerase chain reaction (PCR) products following DNA amplification of the target sequence of the Factor-V gene and factor II gene, respectively. Oligonucleotides used as primers were: 5'-CATACTACAGTGACGTGGAC-3' and 5'-TGTTCT CTTGAAGGAAATGC-3' for Factor-V Leiden; 5'-TCTA GAAACAGTTGCCTGGC-3' and 5'-ATAGCACTGGG AGCATTGAAGC-3' for the G20210A variation of the Prothrombin $\mathrm{T}$ gene. A reaction mixture consist of DNA, forward and revered primer and nuclease free water were added into PCR tubes using ready mix (Maxime PCR PreMix,i-Taq for $20 \mu \mathrm{l}$ ). The mixture was loaded into thermocycler according to the specific temperature profile. The PCR was performed in $35 \mathrm{cy}$ cles consisting of denaturation at $94{ }^{\circ} \mathrm{C}$ for $30 \mathrm{~s}$, annealing at $63{ }^{\circ} \mathrm{C}$ for $30 \mathrm{~s}$, extension at $72{ }^{\circ} \mathrm{C}$ for $30 \mathrm{~s}$, and final extension at $72{ }^{\circ} \mathrm{C}$ for $5 \mathrm{~min} .1 .5 \%$ agarose (iNtRON, Biotechnology) was prepared from $1 \mathrm{x}$ TBE and $5 \mu \mathrm{l} \mathrm{PCR}$ products were loaded, run on the gel for $30 \mathrm{mins}$ and visualized on UV transllimantor. The resulting PCR product for Factor-V 206-bp digested with $10 \mu \mathrm{l}$ of DNA restriction enzyme $M n I 1$ (New England Biolabs ${ }^{\oplus}$ Inc.), and resulted in 3 fragments their length are 36, 47 and $123 \mathrm{bp}$ for wild allele G/G, 2 fragments for mutant allele (47 and $159 \mathrm{bp}$ ) A/A and heterozygote allele resulted in four fragments $(36,47,123$ and $159 \mathrm{bp})$ A/G, Fig. 1. While, Prothrombin PCR product $345 \mathrm{bp}$ digested with

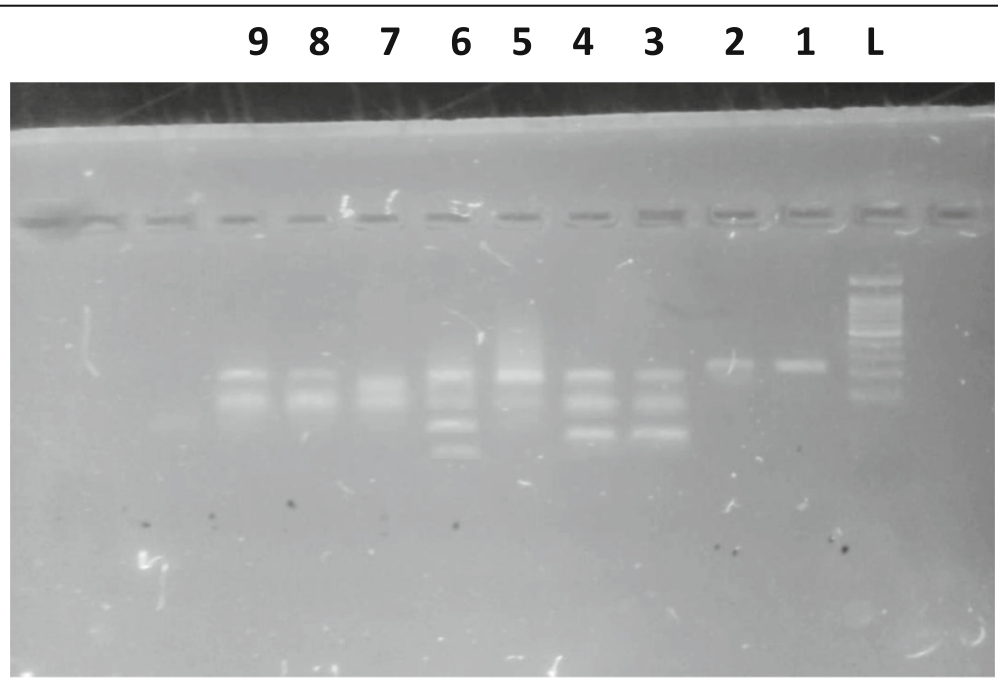

Fig. 1 PCR-RFLP analysis for Factor-V Leiden G1691A polymorphism. Two fragments of $47 \mathrm{bp}$ and $159 \mathrm{bp}$ indicate mutant homozygous (A/A), three fragments of $36 \mathrm{bp}, 47 \mathrm{bp}$ and $123 \mathrm{bp}$ for wild type homozygous (G/G) and four fragments of $36 \mathrm{bp}, 47 \mathrm{bp}, 123 \mathrm{bp}$ and $159 \mathrm{bp}$ indicate $A / \mathrm{G}$ genotype. Lane $L$ show the 100 bp ladder; Lane 1 and 2 undigested PCR products. Lane 3 and 4 indicate wild type homozygous (G/G); 5, 7-9 homozygous mutant (A/A) and Lane 6 represents heterozygous (A/G) genotype 
Table 1 Comparing the mean (SD) of the sociodemographic characteristics between women with preeclampsia and the controls

\begin{tabular}{llll}
\hline Variables & $\begin{array}{l}\text { Preeclampsia } \\
N=(180)\end{array}$ & $\begin{array}{l}\text { Controls } \\
N=(180)\end{array}$ & P-value \\
\hline Age, year & $28.9(5.2)$ & $28.8(4.9)$ & 0.884 \\
Parity & $3.0(1.8)$ & $2.7(1.7)$ & 0.071 \\
Body mass index, $\mathrm{Kg} / \mathrm{m}^{2}$ & $24.5(2.2)$ & $24.5(2.2)$ & 0.995 \\
Hemoglobin, $\mathrm{g} / \mathrm{dl}$ & $10.3(1.4)$ & $10.6(1.6)$ & 0.101 \\
\hline
\end{tabular}

$20 \mathrm{U}$ of Hind-III (New England Biolabs ${ }^{\oplus}$ Inc.), and resulted in undigested PCR product for wild type G/G. Two fragments for mutant allele A/A (322 and $23 \mathrm{bp}$ ) and 3 fragments for heterozygote allele A/G (322, 23 and $345 \mathrm{bp}$ ). Genotyping for factor $\mathrm{V}$ and prothrombin is further confirmed by DNA sequencing for the PCR product by using the same primers pairs and it is done in Macrogen Inc., South Korea.

The sample size was calculated as for case -control study 1: 1ratio and the difference in the proportions of variation between the cases and controls. It was assumed that Factor-V Leiden variation would be in $7.0 \%$ of the pregnant women with preeclampsia and $1 \%$ in pregnant women with no complication. This rate was assumed from our previous report on Factor-V Leiden variation among pregnant Sudanese women with deep venous thrombosis [22]. This would give the study at least $80 \%$ power and the difference of 0.05 at $\alpha$ level [23].

\section{Statistics}

Data were entered in computer sing SPSS for Windows for data analyses. The clinical data were compared between women with preeclampsia and controls by $t$-test and chi-square test for continuous and categorized data, respectively. Hardy-Weinberg equilibrium (HWE) was conducted by comparing of the observed frequencies of the different genotype distribution with their expected frequency under HW in the controls using Pearson's chi-square $\left(X^{2}\right)$ statistical test [24]. Pearson's chi-square $\left(\chi^{2}\right)$ statistical test was used to compare the alleles difference between the cases and controls. A two-sided $P$ value $<0.05$ was considered statistically significant.

\section{Results}

There was no significant difference in the age, parity, BMI and the other characteristics between the cases (preeclampsia) and the controls (180 women in each arm), Table 1. There were $63(35.0 \%)$ and 117 (65.0\%) women with severe and mild preeclampsia, respectively. The cases of preeclampsia were early preeclampsia in 24 (13.3\%) women only and the remaining women 156 (86.7\%) had late preeclampsia. Genotypes distribution of Factor- $V$ Leiden1691G/A in controls was in accordance with the HWE $(P>0.05)$.

The Factor-V Leiden-variation was present in $9.6 \%$ of patients compared to $0.6 \%$ of the controls, $P<0.001$ ( $\mathrm{OR}=18.60,95 \% \mathrm{CI}=2.38-136.1)$. The homozygous variation $\mathrm{A} / \mathrm{A}$ were detected Only in 4 patients (6.3\%) with severe preeclampsia while, none of the controls, Table 2. Prothrombin G20210A variations were not detected, neither in cases nor in controls.

\section{Discussion}

The main findings of the current study were the significant association between Factor-V Leiden-variation and preeclampsia. We have recently observed that Sudanese women with severe preeclampsia (compared with controls) had significantly higher levels of thrombin-activatable fibrinolysis inhibitor, and significantly lower plasminogen-activated inhibitor 2 level [25]. In line with our findings (association between Factor-V Leiden and preeclampsia) previous studies reported significant associations between the preeclampsia and Factor-V [8-10]. Interestingly in their a meta-analysis Dudding et al [26] showed that Factor-V Leiden increased the risk of preeclampsia by almost $50 \%$. Likewise Lin and August [27] in their systemic review and meta-analyses which included 31 studies (7522 patients) reported that over all women with Factor-V Leiden were at 1.81 higher risk of preeclampsia. In contrary previous study found no association between preeclampsia and factor $\mathrm{V}$ Leiden $[11,12]$. A systematically review showed no association of Factor-V Leiden with preeclampsia [28].

Table 2 Comparing the genotypes and alleles of Factor-V Leiden between women with preeclampsia and the controls

\begin{tabular}{|c|c|c|c|c|c|c|}
\hline \multirow[t]{2}{*}{ Genotypes } & \multicolumn{2}{|c|}{ Preeclampsia (180) } & \multicolumn{2}{|c|}{ Controls (180) } & \multirow[t]{2}{*}{ OR (95\% Cl) } & \multirow[t]{2}{*}{$P$-value } \\
\hline & $\mathrm{N}$ & $\%$ & $\mathrm{~N}$ & $\%$ & & \\
\hline GG & 163 & 90.6 & 179 & 99.4 & Reference & \\
\hline GA & 13 & 7.2 & 1 & 0.6 & $14.2(1.84-110.3)$ & 0.011 \\
\hline AA & 4 & 2.2 & 0 & 0 & $9.88(0.52-185.1)$ & 0.053 \\
\hline $\mathrm{GA}+\mathrm{AA}$ & 17 & 9.6 & 1 & 0.6 & $18.60(2.38-136.1)$ & $<0.001$ \\
\hline Allele A & 21 & 5.8 & 1 & 0.3 & $22.24(2.97-166.30)$ & $<0.001$ \\
\hline Allele G & 339 & 94.2 & 359 & 99.7 & Reference & \\
\hline
\end{tabular}


In the current study Factor- $V$ Leiden-variation was present in $9.6 \%$ of women with preeclampsia compared with $0.6 \%$ of the controls. A similar rate $(9.1 \%)$ of Factor-V Leiden was reported in four of 44 preeclamptic women in Tunisia [19]. This rate (9.6\%) of Factor V Leiden in our study was lower than rate of the Factor- $V$ Leiden variation reported among patients with preeclampsia in different setting e.g. 15 and $20 \%$ in Germany [29, 30], 26\% in Israel [31], 15\% in Sweden [32] and 18.8\% in Hungaria [10]. However, a lower rate in Lindqvist's prospective study, only $1.9 \%$ of pregnant women with Factor-V Leiden variation developed preeclampsia, compared to $1.5 \%$ without the variation [32]. Likewise, a lower rate of Factor- $\mathrm{V}$ Leiden was reported in preeclamptic women in Italy $7.2-5.2 \%[8,33]$. In south Africa Factor-V Leiden was not detected in either the preeclamptic women or the control groups [20]. It is worth to be mentioned that our results should be compared with cautious with the results of these studies. Firstly, the difference in ethnicity in the different settings should be remembered. Secondly, types of preeclampsia were enrolled in the different studies e.g. severe and mild, early and late preeclampsia.

We did not detect Prothrombin gene variations neither in the cases nor in the controls. This in line with previous studies reported results $[8,9,12,31,33,34]$. Furthermore, a systematic reviews of only prospective cohort studies [28] showed no associations. Interestingly in South African prothrombin polymorphisms, the variant gene allele was not detected in the investigated cases (preeclampsia) or control groups [20].

\section{Conclusions}

In this study high prevalence of Factor $\mathrm{V}$ Leiden gene variation G1691A compared to healthy controls is observed, which provide an evidence of involvement of Factor V Leiden in the precipitations of preeclampsia in Sudanese women. Prothrombin gene variation G20210A is not associated with preeclampsia in this setting.

\section{Abbreviations}

BMI: Body mass index; EDTA: Ethylene diamine tetra acetic acid; HELLP syndrome: Hemolysis, elevated liver enzymes, low platelet count; HWE: Hardy-Weinberg Equilibrium; PCR: Polymerase chain reaction; PCRRFLP: Polymerase chain reaction-restriction fragment length polymorphism; TBE: Tris Base/Borate/EDTA; UV: Ultra Violet

\section{Acknowledgements}

The authors are very grateful to all the patients for their cooperation. Authors wish to thank Dr. Motasim Badri for re-checking the statistics.

Funding

Not received.

\section{Availability of data and materials}

All data generated or produced from this study are included in this manuscript. Raw data of the study will be available upon request after publication.

\section{Authors' contributions}

NAA, HAA and IEA carried out the study and participated in the statistical analysis and procedures. NAA and SEGE carried out the practical part of the study. $\mathrm{HZH}$ and IA coordinated and participated in the design of the study, statistical analysis and the drafting of the manuscript. All the authors read and approved the final version.

Ethics approval and consent to participate

The study received ethical clearance from Al-Neelain University Ethics review board. All participants provide signed informed consent before enrolment.

\section{Consent for publication}

Not applicable.

\section{Competing interests}

The authors declare that they have no competing interests.

\section{Publisher's Note}

Springer Nature remains neutral with regard to jurisdictional claims in published maps and institutional affiliations.

\section{Author details}

${ }^{1}$ Department of Biochemistry and Molecular Biology, Faculty of Medicine, Al-Neelain University, P.O. Box: 12702, Khartoum, Sudan. ${ }^{2}$ Faculty of Medicine, University of Khartoum, Khartoum, Sudan. ${ }^{3}$ Department of Epidemiology, Tropical Medicine Research Institute, Khartoum, Sudan.

Received: 27 November 2018 Accepted: 13 December 2018 Published online: 05 January 2019

\section{References}

1. American College of Obstetricians and Gynecologists. ACOG practice bulletin. Diagnosis and management of preeclampsia and eclampsia. Number 33, January 2002. American College of Obstetricians and Gynecologists. Int J Gynaecol Obstet. 2002;77:67-75.

2. Lo JO, Mission JF, Caughey AB. Hypertensive disease of pregnancy and maternal mortality. Curr Opin Obstet Gynecol. 2013;25:124-32.

3. Abalos E, Cuesta C, Grosso AL, Chou D, Say L. Global and regional estimates of preeclampsia and eclampsia: a systematic review. Eur J Obstet Gynecol Reprod Biol. 2013;170:1-7.

4. Redman CW, Sargent IL. Latest advances in understanding preeclampsia. Science. 2005:308:1592-4.

5. Redman CW. Current topic: pre-eclampsia and the placenta. Placenta. 1991; 12:301-8.

6. Lisowska M, Pietrucha T, Sakowicz A. Preeclampsia and related cardiovascular risk: common genetic background. Curr Hypertens Rep. 2018:20:71.

7. Agorastos T, Karavida A, Lambropoulos A, Constantinidis T, Tzitzimikas S, Chrisafi S, et al. Factor V Leiden and prothrombin G20210A mutations in pregnancies with adverse outcome. J Matern Neonatal Med. 2002;12:267-73.

8. Benedetto C, Marozio L, Salton L, Maulà V, Chieppa G, Massobrio M. Factor $\checkmark$ Leiden and factor II G20210A in preeclampsia and HELLP syndrome. Acta Obstet Gynecol Scand. 2002;81:1095-100.

9. Muetze S, Leeners B, Ortlepp JR, Kuse S, Tag CG, Weiskirchen R, et al. Maternal factor $V$ Leiden mutation is associated with HELLP syndrome in Caucasian women. Acta Obstet Gynecol Scand. 2008:87:635-42.

10. Nagy B, Tóth T, Rigó J, Karádi I, Romics L, Papp Z. Detection of factor V Leiden mutation in severe pre-eclamptic Hungarian women. Clin Genet. 1998;53:478-81.

11. Berks D, Duvekot JJ, Basalan H, De Maat MPM, Steegers EAP, Visser W. Associations between phenotypes of preeclampsia and thrombophilia. Eur J Obstet Gynecol Reprod Biol. 2015;194:199-205.

12. Kahn SR, Platt R, McNamara H, Rozen R, Chen MF, Genest J, et al. Inherited thrombophilia and preeclampsia within a multicenter cohort: the Montreal Preeclampsia Study. Am J Obstet Gynecol. 2009;200:151 e1-9; discussion e1-5.

13. Mello G, Parretti E, Marozio L, Pizzi C, Lojacono A, Frusca T, et al. Thrombophilia is significantly associated with severe preeclampsia: results of a large-scale, case-controlled study. Hypertens (Dallas, Tex 1979). 2005:46: 1270-4. https://doi.org/10.1161/01.HYP.0000188979.74172.4d. 
14. Wang X, Bai T, Liu S, Pan H, Wang B. Association between thrombophilia gene polymorphisms and preeclampsia: a meta-analysis. PLoS One. 2014;9: e100789. https://doi.org/10.1371/journal.pone.0100789.

15. Silver RM, Zhao Y, Spong CY, Sibai B, Wendel G, Wenstrom $K$, et al. Prothrombin gene G20210A mutation and obstetric complications. Obstet Gynecol. 2010;115:14-20. https://doi.org/10.1097/AOG.0b013e3181c88918.

16. Malek-Khosravi S, Rahimi Z, Rahimi Z, Jalilvand F, Parsian A. Thrombophilic mutations and susceptibility to preeclampsia in Western Iran. J Thromb Thrombolysis. 2012;33:109-15. https://doi.org/10.1007/s11239-011-0653-y.

17. Ali AA, Okud A, Khojali A, Adam I. High incidence of obstetric complications in Kassala Hospital, Eastern Sudan. J Obstet Gynaecol. 2012;32:148-9.

18. Ali AAA, Rayis DA, Abdallah TM, Abdullahi H, Adam I. Hypertensive disorders in pregnancy in Kassala hospital, Eastern Sudan. 2011;04:656-9.

19. Klai S, Fekih-Mrissa N, Rachdi R, Gritli N. The status of Thrombophilic defects and non-O blood group as risk factors for gestational vascular complications among Tunisian women. Acta Haematol. 2011;125:115-20.

20. Hira B, Pegoraro RJ, Rom L, Moodley J. Absence of factor V Leiden, thrombomodulin and prothrombin gene variants in black south African women with pre-eclampsia and eclampsia. BJOG. 2003;110:327-8.

21. Miller SA, Dykes DD, Polesky HF. A simple salting out procedure for extracting DNA from human nucleated cells. Nucleic Acids Res. 1988;16:1215.

22. Awad-Elkareem A, Elzaki SG, Khalid H, Abdallah MS, Adam I. A low rate of factor $V$ Leiden mutation among Sudanese women with deep venous thrombosis during pregnancy and puerperium. J Obstet Gynaecol (Lahore). 2017;37:963-4

23. Das S, Mitra K, Mandal M. Sample size calculation: Basic principles. Indian J Anaesth. 2016;60:652.

24. Michael C. A simple calculator to determine whether observed genotype frequencies are consistent with Hardy-Weinberg equilibrium. 2008;2008. https://view.officeapps.live.com/op/view.aspx?src=http\%3A\%2F\%2Fwww.drpetrek.eu\%2Fdocuments\%2FHWE.xls.

25. Elzein HO, Muddathir ARM, Rida M, Rayis DA, Elhassan EM, Adam I. Fibrinolysis parameters in Sudanese women with severe preeclampsia. Hypertens Pregnancy. 2016;35:559-64.

26. DUDDING T, HERON J, THAKKINSTIAN A, NURK E, GOLDING J, PEMBREY M, et al. Factor $V$ Leiden is associated with pre-eclampsia but not with fetal growth restriction: a genetic association study and meta-analysis. J Thromb Haemost. 2008;6:1868-75.

27. Lin J, August P. Genetic thrombophilias and preeclampsia: a meta-analysis. Obstet Gynecol. 2005;105:182-92.

28. Rodger MA, Betancourt MT, Clark P, Lindqvist PG, Dizon-Townson D, Said J, et al. The association of factor $V$ Leiden and prothrombin gene mutation and placenta-mediated pregnancy complications: a systematic review and meta-analysis of prospective cohort studies. PLoS Med. 2010;7:e1000292.

29. Von Tempelhoff GF, Heilmann L, Spanuth E, Kunzmann E, Hommel G. Incidence of the factor $V$ Leiden-mutation, coagulation inhibitor deficiency, and elevated antiphospholipid-antibodies in patients with preeclampsia or HELLP-syndrome. Thromb Res. 2000;100:363-5.

30. Krauss T, Augustin HG, Osmers R, Meden H, Unterhalt M, Kuhn W. Activated protein $C$ resistance and factor $V$ Leiden in patients with hemolysis, elevated liver enzymes, low platelets syndrome. Obstet Gynecol. 1998;92:457-60.

31. Kupferminc MJ, Eldor A, Steinman N, Many A, Bar-Am A, Jaffa A, et al. Increased frequency of genetic thrombophilia in women with complications of pregnancy. N Engl J Med. 1999;340:9-13.

32. Lindqvist PG, Svensson PJ, Marsaál K, Grennert L, Luterkort M, Dahlbäck B. Activated protein C resistance (FV:Q506) and pregnancy. Thromb Haemost. 1999:81:532-7.

33. D'Elia AV, Driul L, Giacomello R, Colaone R, Fabbro D, Di Leonardo C, et al. Frequency of factor $\mathrm{V}$, prothrombin and methylenetetrahydrofolate reductase gene variants in preeclampsia. Gynecol Obstet Investig. 2002;53:84-7.

34. Alfirevic Z, Mousa HA, Martlew V, Briscoe L, Perez-Casal M, Toh CH. Postnatal screening for thrombophilia in women with severe pregnancy complications. Obstet Gynecol. 2001;97(5 Pt 1):753-9.

Ready to submit your research? Choose BMC and benefit from:

- fast, convenient online submission

- thorough peer review by experienced researchers in your field

- rapid publication on acceptance

- support for research data, including large and complex data types

- gold Open Access which fosters wider collaboration and increased citations

- maximum visibility for your research: over $100 \mathrm{M}$ website views per year

At BMC, research is always in progress.

Learn more biomedcentral.com/submissions 